\title{
Die behoefte aan apologetiese toerusting reeds by voorskoolse kategese
}

\section{Authors:}

Henk G. Stoker 1

G. Jonker Venter ${ }^{1}$ (I)

\section{Affiliations:}

${ }^{1}$ Unit for Reformational Theology and the Development of the SA Society, Faculty of Theology, North-West University, Potchefstroom, South Africa

Corresponding author: Henk Stoker,

henk.stoker@nwu.ac.za

Dates:

Received: 02 Feb. 2021 Accepted: 28 July 2021

Published: 29 Oct. 2021

How to cite this article: Stoker, H.G. \& Venter, G.J., 2021, 'Die behoefte aan apologetiese toerusting reeds by voorskoolse kategese', In die Skriflig 55(2), a2722. https://doi.org/10.4102/ids. v55i2.2722

\section{Copyright:}

(c) 2021. The Authors. Licensee: AOSIS. This work is licensed under the Creative Commons Attribution License.

Read online:
The need for apologetic equipment already in preschool catechesis. From a young age, children are busy making sense of the world around them. Their worldview is formed by influences and/or guidance and their own intrinsic participation. With the availability of information provided by the media in the 21st century, Christian children are exposed to not only a Christian worldview, but also to other dominating worldviews. This exposure can have a negative effect on the formation of a Christian worldview if not treated correctly. When leading Christian researchers assume the prerequisite that pre-school children do not have the ability to grasp aspects of faith due to their so-called inability for abstract thoughts, the results will be the underemphasis, neglect and even disapproval of equipment in terms of a Christian biblical worldview. The result of this view is that non-biblical worldviews will dominate and shape Christian children's thoughts from an early age, while there is little to no equipment guiding them. This occurs notwithstanding that the Word of God demands believers to educate their children and to equip them from an early age with the necessary foundational tools and resources. Apologetical equipment in the understanding of God, man and the world ought to be part of this education in faith that leads to a biblical and Christian worldview from a young age.

Contribution: In their first six years, children form important concepts and presuppositions that could influence and affect the rest of their lives. Especially also through the stories they watch and listen to, they are confronted with conflicting ideas and concepts from which they must make sense. Sufficient apologetic and catechetical resources on the cognitive level of preschool children should be provided to parents and educators of these children. These materials of which worldviews should be an integral part of, can and should guide these young believers in the consideration of conflicting ideas and even the defence of what they believe.

Keywords: apologetics; worldviews; preschool children; kindergarten; catechetics; equipment; education.

\section{Inleiding}

Wanneer Christene erns maak met die opdrag van die Here soos in Deuteronomium 6:6-7 opgeteken, ${ }^{1}$ behoort hulle moeite te doen om hulle kinders in die leer van die Here te onderrig (kyk Breed 1994:256-265). Die verduideliking van die skepping van alles uit niks, die doel van alles, norme wat daarvoor geld, asook die uiteinde van ons lewe op aarde, help kinders van kleins af om verskeie aspekte van Wie die Here is, te leer ken. Dit vorm terselfdertyd 'n belangrike deel van hulle wêreldbeskouing. Ouers en ander opvoeders van voorskoolse kinders ${ }^{2}$ kan hierin gehelp word deur die daarstel van voldoende en gerigte Christelike kurrikula wat ook die kompeterende God-, mens- en wêreldbeskouings waarmee kinders te doen kry, hanteer. Juis in 'n tyd van die verval van die Christelike godsdiens, behoort meer erns gemaak te word om ouers, ander opvoeders en voorskoolse kinders in 'n Christelike wêreldbeeld apologeties toe te rus. ${ }^{3}$

Breed (1994:256-259, 264-265) stel egter met reg dat kinders van kleins af God, sy verbondsliefde en -trou, asook wat dit inhou om in 'n intieme verhouding met Hom te leef in hulle ouerhuis moet

1.In Deuteronomium 6:6-7 word die volk van God opdrag gegee om dit wat hulle van Hom leer by hulle kinders in te skerp "en met hulle daaroor praat as jy in jou huis is en as jy op pad is, as jy gaan slaap en as jy opstaan' (kyk ook soortgelyke dele in Spr 1:8; 3:1-2, 11-12; Ps 103:13; Ef 6:1-4).

2.Hierdie artikel word veral toegespits op die ouderdomsgroep wat as voorskoolse kinders bekendstaan. Tensy spesifiek anders vermeld word, verwys kinders in hierdie artikel, sowel as die begrip kleuters, na die ouderdomsgroep van alle voorskoolse kinders en dien dit dus as wisselterm van voorskoolse kinders onder die ouderdom van sewe jaar.

3.Wat voorskoolse kinders se kognitiewe ontwikkelingsfase betref, klassifiseer sielkundiges hierdie kinders in die ouderdomsgroep onder sewe jaar oor die algemeen as die vroeë kinderjare-fase (vgl. Louw \& Louw 2014:7-8). Daar bestaan 'n verskeidenheid van teorieë rakende kinders se ontwikkeling soos gedagte- en inligtingprosessering (Louw \& Louw 2014:157-173), die morele ontwikkeling van Kohlberg (Weiten 2014:443-446), ensovoorts. Die mees bekende teorieë aangaande kinders se kognitiewe ontwikkeling is dié van Jean Kohlberg (Weiten 2014:443-446), ensovoorts. Die mees bekende teorieë aangaande kinders se kognitiewe ontwikkeling is dié van Jean
Piaget en Lev Vygotski (Shaffer \& Kipp 2010:281). Volgens Piaget is voorskoolse kinders in die pre-operasionele fase waar kinders taal en simbole gebruik om na idees en objekte te verwys (Louw \& Louw 2014:25-26; Shaffer \& Kipp 2010:250-252). Erikson se teorie van voorskoolse kinders se ontwikkeling word later in die artikel behandel. 
leer ken. Deur die ouers se eie liefdevolle en intieme verhouding met hulle kinders, bied hulle 'n basis van God se verbondsliefde en sy sorg waardeur die kinders uiteindelik tot liefde vir God begelei word.

Die kerk van die Here Jesus het in opdrag van Hom 'n belangrike taak om sy lammers van kleins af op te voed (Joh 21:15). Hierdie artikel gaan van die standpunt af uit dat geloofsonderrig nie alleen die taak van gelowige ouers is nie, maar ook dié van die huisgesin van God - die gemeente (1 Tim 3:15-16). ${ }^{4}$ In die Ou Testament was kinders deel van die godsdienstige seremonies en dienste waar profete kinders aan God se trou en beloftes herinner het sodat hulle God kon vertrou en Hom ook getrou kon dien. Hierdie vertroue kan byvoorbeeld gesien word in die gelowige dogtertjie uit Israel wat selfs in die vreemde haar eienaar kon vertel van die Here se profeet in Samaria (2 Kon 5:1 e.v.). In sy dienswerk het die priester kinders onderrig om God se heiligheid en almag te besef en in ontsag na Hom te luister soos die geval van die priester Eli met die seun Samuel (1 Sm 3:1 e.v.). In die Nuwe Testament het die apostel Petrus die opdrag gekry om in geloofsversorging eers die lammers van die Here te laat wei voor die opdrag om sy skape op te pas en hulle te laat wei (Joh 21:15-17). ${ }^{5}$ Die Ou-Testamentiese seremoniële feeste sowel as die Nuwe-Testamentiese sakramente bied op hulle beurt onderrig in terme van die herinnering aan God se skeppingsen heilsdade waardeur God in die hede verheerlik kan word.

Hoewel voorskoolse kinders nog verstandelik en andersins ontwikkel, is hulle aktief besig om van die werklikheid rondom hulle sin te maak, ${ }^{6}$ en word hulle wêreldbeskouing reeds deur hulle eie intrinsieke deelname sowel as eksterne begeleiding gevorm (Louw \& Louw 2014:168). Daarom is dit ook belangrik om voorskoolse kinders by doelgerigte geloofsopvoeding in te sluit wat die uitbou van die waarheid bevat, asook die afwys van dwaling op 'n opregte en respekvolle wyse - dus apologetiese toerusting. ${ }^{7}$ So kan hulle na 'n bybels-Christelike wêreldbeskouing begelei word. ${ }^{8}$ net een Wese is wat waarlik God is en kan wees. Dit word onder andere deur Christelike kerke in die algemeen in die Geloofsbelydenis van Athanasius, artikels 3-20 bely en deur die Protestantse kerke in artikel 1 van die Nederlandse Geloofsbelydenis (NGB). God openbaar Hom aan ons in die Bybel as Woord van God (NGB art. 3). Hy waarsku ons daarin teen valse profete, apostels of leraars wat ' $n$ ander en dus valse God-, mens- en wêreldbeskouing het. Daarteenoor word Bybelgelowiges opdrag gegee om die ware verstaan van God, mens en wêreld by Christenkinders in te skerp.

5.Wat die ampsdraers in die Nuwe Testament se lering betref, word groot klem geplaas op toerusting vir die dienswerk en roeping in en vir die opbou van die gemas op toerusting vir die dienswerk wat deur Jesus Christus se koms en die uitstorting van die Heilige Gees verwerklik is.

6.Piaget beweer dat hierdie kinders nie die vermoë het om abstrak te dink nie, maar ander sielkundiges soos Fowler, Vygotski en Erikson verskil van hom (Venter 2019:36).

7.Apologetiese toerusting by voorskoolse kinders betrek die vakwetenskap van Apologetiek waar laasgenoemde ' $n$ regverdiging vir die waarhede van die Christelike geloof bied (Craig 2008:15), en dit toegepas word om voorskoolse kinders met die bybelse waarheid op só ' $n$ wyse toe te rus dat hulle nie alleen sal weet wat of waarom hulle hierdie waarheid glo nie, maar dit ook op hulle vlak aan ander mense kan kommunikeer. Hierdie artikel fokus veral op die wêreldbeskoulike aspekte wat as apologetiese toerusting sal bydra en dien om kinders toe te rus met ' $n$ verstaan en begrip van die werklikheid van God, die mens en sy wêreld.

8.Die fokus van hierdie artikel is spesifiek op Christenkinders onder sewe jaar, en nie op kinders in die algemeen in ' $n$ spesifieke land of bevolkingsgroep nie. Dit beskou die singewing wat Christenkinders benodig nie as kultuurgebonde nie. Die bybels-Christelike wêreldbeskouing in hierdie artikel verwys onder meer na die lewensuitkyk en uitlewing daarvan soos dit voortdurend deur die Bybel en Christelike lewensuitkyk en uit
Die probleemstelling wat hierdie artikel identifiseer, is dat wêreldbeskoulike onderrig aan voorskoolse kinders nie voldoende aandag in Christelike kerke se kategeseklasse en ouerhuise geniet nie met die noodwendige gevolg dat hierdie kinders hulle moeilik ten opsigte van hulle Christelike geloof kan verantwoord. Die artikel wil 'n bewustheid van hierdie leemte skep, asook hoe dit hanteer kan word sodat hierdie kinders die nodige apologetiese toerusting sal ontvang met betrekking tot 'n bybels-Christelike wêreldbeskouing.

\section{Die tekort aan kategetiese onderrig by voorskoolse kinders \\ Voorskoolse onderrig - aandrang en teenstand}

Anders as in al die eeue tevore, het die vrylik beskikbare sosiale media van die een-en-twintigste eeu nuwe uitdagings selfs vir voorskoolse kinders geskep waar kompeterende wêreldbeskouings aan hulle uitgebeeld word. Ten spyte van die belangrikheid van geloofsopvoeding en die gepaardgaande toerusting om kinders se bybelse wêreldbeskouing te versterk, is daar steeds navorsers wat van die veronderstelling uitgaan dat kinders nie God- en wêreldbeskoulik begrond moet word nie, omdat hulle kwansuis eers in hulle latere ontwikkeling die vermoë sou hê om geloofsake te begryp.

In sy boek oor Christelike opvoeding vir kinders, stel Richards (1975:168-171) dat, indien Piaget en Kohlberg se teorieë oor vroeë kinderontwikkeling aangehang word, die afleiding gemaak word dat kinders nie die vermoë het om abstraktheid te verstaan nie. Die gevolg is dan 'that teaching the Bible to children really is not terribly important after all' (Richards 1975:170). Malan (1979:13-16) stel dat klein kinders nie in godsdienstige feite belangstel nie, maar godsdiens deur hulle ervaring aanleer (ervaringswêreld, gevoelens en gesindhede). Sodoende sal klein kinders, volgens haar, eerder op die liefde wat uit die evangelie straal reageer voordat hulle in die evangelie-boodskap (van God wat ons deur Christus liefhet) sal belangstel. Daarom, beweer sy, hoef klein kinders nie terme soos verlossing, versoening, maagdelike geboorte, ensovoort geleer te word nie. Theunissen (1978:17) kom tot die gevolgtrekking dat baie van die Bybelverhale wat juis goeie insig in God- en wêreldbeskouing gee, vir klein kinders onverstaanbaar is en beveel aan dat dit liefs vermy moet word totdat die kind oud genoeg is om vanuit sy eie leefwêreld en ervaring daarvan sin te maak.

Nieteenstaande die sienings wat veral gegrond is op die ontwikkelingsielkunde van Piaget wat geloofsopvoeding en lewensbeskoulike toerusting op voorskoolse vlak onderbeklemtoon, nalaat of selfs afwys, stel van hierdie navorsers tog dat voorskoolse kinders op een of ander manier by geloofsopvoeding ingesluit moet word.

Theunissen (1978:1-14) meen byvoorbeeld dat, alhoewel kinders net konkrete dinge kan verstaan en 'n onvermoë het om abstrak te dink, dit bloot 'n agterstand teenoor 
volwassenes is, en dat bybelse waarhede tog op kinders se ontwikkelingsvlak aangebied moet word, selfs al verstaan hulle dit nog nie.

Hierdie onduidelikheid rakende klein kinders se genoegsame begrip oor geloofsake en hoe hulle by geloofsopvoeding betrek moet word, duur tot in die een-en-twintigste eeu voort. So gaan Keeley (2008) van die veronderstelling uit dat kinders nie abstrak kan dink nie, en daarom nie die vermoë het om geloof te begryp nie:

Much of Piaget's theory has to do with the ability to handle abstraction. Simply put, children can't deal with abstract ideas. This has a number of implications for teachers, but it is also important for those of us concerned with children's spirituality. (pp. 100-101)

Selfs Van der Merwe (2004:364) wat op kategetiese onderrig fokus, stel dat 'n kleuter 'nie abstrak dink of redeneer nie en daarom is dinge vir hom konkreet'. Hy maak egter steeds die kontrasterende gevolgtrekking dat kinders wel in terme van hulle Godsbegrip abstrak kan dink.

'n Ongelukkige gevolg van hierdie sienings oor geloofsonderrig is dat daar min tot geen aandag aan apologetiese toerusting van jonger kinders in die vorming van 'n Christelike wêreldbeskouing gegee is nie.

In 'n tyd waar die media verskillende en teenstrydige idees toenemend effektief aan klein kinders deurgee, word die voorskoolse Christenkinders van ons tyd op verskeie terreine met ander wêreldbeskouings gebombardeer. Die gevolg is, soos studies van onder andere die Barna-groep aantoon, dat die meerderheid Christenkinders van Generasie Z selfs al op 'n laerskoolvlak en ook daarna nie in staat is om hulleself ten opsigte van die Christelike wêreldbeskouing te kan verantwoord nie - juis omdat hulle self nie 'n Christelike wêreldbeskouing het nie (Barna Group 2018:24-26).

'n Belangrike rede hiervoor is dat kinders se fundering en geloofsgroei nie die nodige prioriteit by ouers en ander opvoeders ontvang nie (Strommen \& Hardel 2008:16). Bowendien is ' $n$ groot deel van Christen-huisgesinne nie meer in staat of toegerus om geloofsgroei by hulle kinders te kweek nie (De Klerk \& Van Helden 2011:3) en kan hulle dus ook nie hulle kinders toerus om hulleself ten opsigte van hulle Christelike geloof te verantwoord nie.

\section{Die siening van voorskoolse kinders is aan die verander}

In die laaste paar dekades het navorsing van veral sosioloë, sielkundiges en filosowe ten opsigte van kinderontwikkeling en selfs geloofsontwikkeling getoon dat klein kinders tot heelwat meer in staat is as wat vroeër geglo is. Ongelukkig is daar, volgens Bunge (2001:1-3), steeds min en slegs losstaande bydraes vanuit teologiese wetenskappe hiertoe gemaak.

Reeds 'n halfeeu gelede het Mensing (1972:13-14) daarop gewys dat die ontwikkelingsielkunde al sedert die negentiende eeu spesiale aandag aan opvoeding by babas en jong kinders gee, en dat byna alle opvoedkundige boeke van die twintigste eeu ook op die belangrikheid van die vroeë kinderjare fokus. Theunissen (1978:v) maak in daardie selfde tyd melding daarvan dat sielkundiges en opvoedkundiges in die tweede helfte van die twintigste eeu meer aandag aan voorskoolse kinders se vermoë en begrip van godsdienstige waarhede begin skenk het. Sy maak die afleiding dat kinders van vroeg (selfs van geboorte) af aan geloofsopvoeding en -toerusting blootgestel moet word - selfs al verstaan klein kinders nie alles waaraan hulle blootgestel word nie (Theunissen 1978:1-6).

Met dit reeds so lank gelede gesê, wys Yust et al. (2006:2) daarop dat, vanuit Christelike geloofsopvoeding, daar nog nie werklik 'n omvattende bydrae gemaak is in terme van 'n program vir die geestelike ontwikkeling ${ }^{9}$ van jong kinders nie. Ook is daar min teologiese navorsing oor kleiner kinders se morele en geestelike ontwikkeling gedoen (Yust et al. 2006:53-54). Geloofsopvoeding was op die voorbereiding van kinders gefokus om 'n geestelike bewustheid op 'n volwasse vlak te ontwikkel eerder as kinders se geestelike ervarings en opbou volgens hulle eie ontwikkelingsfase (Yust et al. 2006:3).

Die draai van die eeu het tog 'n nuwe oplewing in die bestudering van geestelike ontwikkeling by kinders meegebring (Yust et al. 2006:5). ${ }^{10}$ Religieuse opvoeders en kindersielkundiges het begin om ook vroeë kinderontwikkeling te ondersoek (Yust et al. 2006:55-56). ${ }^{11}$

Voorskoolse kinders is in hulle formatiewe jare op verskillende vlakke van kognitiewe ontwikkeling. Om verdere onderskeiding te maak en dit op geloofsopvoeding toe te pas, kom Erikson se psigologiese stadia van ontwikkeling handig te pas (vgl. Shaffer \& Kipp 2010:44-46). Oorkoepelend kan die ontwikkelingstyd soos volg verdeel word: Kinders tot en met een jaar oud is in 'n stadium waar vertroue die deurslaggewende rol speel, terwyl kinders tussen een en drie jaar besig is om hulle outonomie en eie wil te ontdek. Kinders tussen drie en ses jaar ontwikkel inisiatief, waarin

9.Yust et al. (2006:8) bied 'n definisie vir geestelikheid (spirituality) wat voldoende is vir inter-religieuse gesprekke: 'Spirituality is the intrinsic human capacity for selftranscendence in which the individual participates in the sacred-something greater than the self. It propels the search for connectedness, meaning, purpose, and ethical than the self. It propels the search for connectedness, meaning, purpose, and ethical responsibility. It is experienced, formed, shaped, and expressed through a wide range of religious narratives, beliefs, and practices, and is shaped by many influences
in family, community, society, culture, and nature.'

10. Hierdie beweging het onder andere die volgende studies opgelewer: In 2002 het Christelike kenners vanuit Asië, Europa, Afrika, Amerika en Maleisië rondom Christelike kenners vanuit Asië, Europa, Afrika, Amerika en Maleisië rondom
kinderteologie vergader in 'n poging om 'n debat daaroor van stapel te stuur. In kinderteologie vergader in 'n poging om 'n debat daaroor van stapel te stuur. In
2003 het The American Academy of religion ' $n$ voortgaande gesprek in Kinderjare studies begin. Verdere internasionale konferensies het ook ontstaan, onder andere The international conference on children's spirituality, the children's worldview project, sowel as The children's spirituality-Christian perspectives conference (Yust et al. 2006:5-6).

11.Yust et al. (2006:59-60) stel dat, hoewel eksponente vanuit die Reformasie groot bydraes ten opsigte van kinderopvoeding gemaak het, hulle kinders hoofsaaklik as sondaars beskou het. Op sigself is Calvyn se siening in die geheelbeeld van die leer oor die mens nie verkeerd nie, maar is kinderontwikkeling gevolglik onderbeklemtoon. Tog het Calvyn nie die leer van kinders verontagsaam nie; inteendeel. Yust et al. (2006:59-60) toon verder aan dat ook Jonathan Edwards kinders wat buite Christus is, as slange beskou. Die punt van hierdie inligting is dat, kinders wat buite Christus is, as slange beskou. Die punt van hierdie inligting is dat,
indien sulke sienings in isolasie beskou word of die sondige aard oorbeklemtoon word, dit tot gevolg kan hê dat kinders se ontwikkelingsfases geïgnoreer word en mord, dit tot gevolg kan hê dat kinders se ontwikkelingsfases geïgnoreer word en geloofsvorming en toerusting te bestee nie. 
hulle nuwe dinge in hulle leefwêreld aandurf (Louw \& Louw 2014:22-23). Hierdie indeling bied goeie agtergrond vir die opvoeding van hierdie kindertjies in hulle kennis van God en wêreld.

Dit behoort vanself te spreek dat voorskoolse kinders toegerus moet word om in verhouding met God te leef en as Christene op die regte manier na die wêreld te kyk. Hiervan getuig die geykte gesegde wat aan die Griekse filosoof, Aristoteles toegeskryf word: 'Gee my 'n kind tot hy sewe is, en ek wys jou 'n man.'

\section{'n Bybels-Christelike leer vorm 'n houdbare Christelike wêreldbeskouing by voorskoolse kinders}

In 1961 skryf die bekende Suid-Afrikaanse Christen-filosoof, H.G. Stoker, dat alle mense 'n lewens- en wêreldbeskouing het, selfs al is hulle nie bewus daarvan nie. Hy stel dat ' $n$ lewens- en wêreldbeskouing reeds by jong kinders gevind word, selfs al kan dit nog nie in woorde uitgedruk word nie, en verder dat elkeen se lewens- en wêreldbeskouing deur ander mense soos onder andere jou ouers gevorm word (Stoker 1961:114; vgl. ook Carter 2012:15). Mense ontwikkel baie vroeg in hulle lewe (reeds vanaf babatyd) vooronderstellings of hermeneutiese beginsels waarmee hulle die werklikheid van die wêreld benader om sin te maak van dinge en om hulle wêreld te verstaan (Carter 2012:12). In hierdie verstaanproses funksioneer 'n mens se brein soos 'n sif (wat jou bestaande raamwerk verteenwoordig) waarvolgens inligting verwerk en geliasseer word, terwyl onbekende konsepte in die sif agterbly totdat die brein dit kan verwerk en kategoriseer (Kaiser \& Silva 2007:17-19). Mense is voortdurend besig om hulle raamwerk verder te ontwikkel om te kan sin maak van die werklikheid rondom hulle. Hierdie raamwerk van vooronderstellings is soos 'n bril wat 'n mens opsit om die werklikheid in die wêreld rondom jou te verstaan en te interpreteer (Van der Walt 2010:59).

Valk (2012:160) stel dat 'n mens se wêreldbeskouing jou persepsie van die werklikheid voortdurend inlig en vorm (inform en form). Op so 'n wyse dien 'n mens se wêreldbeskouing as die raamwerk van vooronderstellings wat deur 'n persoonlike hermeneutiek gevorm word, terwyl dit laasgenoemde selfs voorafgaan waarmee mense van hulle verstaan van die werklikheid in alle terreine van die lewe wil sin maak.

Rakende hierdie volgorde beklemtoon Sire (2015:95): 'Ontology must precede epistemology in worldview formation ... that being itself logically precedes the act of knowing.' Indien dit nie waar was nie, sou dit impliseer dat God se bestaan deur menslike epistemologie vervang word. Die gevolg sou wees dat wêreldbeskouings op die basis van menslike outonomie gebou word wat tot 'n verdere gevolgtrekking lei, naamlik dat niemand die waarheid kan toets nie, omdat verstaan van die waarheid voor waarheid self geplaas word (vgl. Sire 2015:91-93).

Die baanbreker gereformeerde apologeet, Cornelius van Til, het die enorme invloed wat wêreldbeskouings op geloofsgroei en -verdediging het, beklemtoon. Deur bloot net na sy definisie van Apologetiek te kyk, is dit duidelik hoe nóú Apologetiek en 'n lewens- en wêreldbeskouing met mekaar in verband staan, selfs in die toerusting van klein kinders: 'Apologetics is the vindication of the Christian philosophy of life against the various forms of the non-Christian philosophy of life' (Edgar 2003:17).

Mense se wêreldbeskouing is die beginpunt van hulle (geloofs-)oortuigings waarvolgens hulle die werklikheid interpreteer. Daarom is die korrekte vorming daarvan by kinders wat nog besig is om hulle wêreldbeskouing grondig te ontwikkel van die grootste belang. In 'n eeu waar daar soveel verskillende wêreldbeskouings is wat op die Goden wêreldbeskouing van voorskoolse kinders aanspraak maak, is dit uiters noodsaaklik dat Christene op toerusting fokus wat kinders in die vorming van die mees akkurate bybels-Christelike wêreldbeskouing kan ondersteun. ${ }^{12}$

Die Bybel swyg nie oor die belangrikheid van kinders en die noodsaaklikheid van toerusting nie: 'The Bible is teeming with direct references to children, childhood, and adult-child relationships' (Bunge 2008:xiv). Hoewel daar 'n reeks Skrifgedeeltes in die Bybel is wat na kinders verwys, kry 'n mens alreeds in Genesis 1 'n tematiese benadering van kinders wat, net soos volwassenes, as mense na die beeld van God geskape is.

Hoewel die konsep beeld van God eksegeties verskeie vrae kan oplewer, ${ }^{13}$ meen Bunge (2008:317-318) dat, vanuit hierdie konsep en die direkte uiteensetting wat in Genesis 1 daarop volg, afgelei kan word dat beeld van God onder andere inhou dat mense relasionele wesens is: eerstens teenoor God, daarna teenoor mekaar, maar ook teenoor die natuur. Omdat mense vrugbaar moet wees en moet vermeerder (Gen 1:28), impliseer dit dat hulle nageslag ook as afstammelinge van Adam en Eva na die beeld van God geskape is (Bunge 2008:321-323).

Richards en Privett (2009:7) som die konsep van kinders in die Bybel omvattend as 'n seëning van God op (vgl. ook May et al. 2005):

After all, the Bible tells us that children are a gift from God. God addresses human beings as complete and whole individuals from before their birth and throughout their lives. Human personhood is not divided up into childhood or adulthood; it is merely personhood irrespective of age, social status or amount of learning, wisdom or experience. God calls each individual human being into a real relationship and to a real vocation, not a potential vocation somewhere in the future. (pp. 26-38)

12.Die mees akkurate word in die artikel gesien as in ooreenstemming met die Bybel en protestantse geloofsbelydenisse.

13.' $n$ Voorbeeld hiervan is of Adam na 'n mens of na die menslike geslag verwys, en of beeld en gelykheid dieselfde is. 
Dit is dus ' $n$ belangrike vraag watter toerusting Christene vir kinders in die vorming van 'n Christelike wêreldbeskouing tydens hulle vormingsjare bied, sodat kinders die wêreld kan verstaan soos God dit openbaar en terselfdertyd staande kan bly teen die negatiewe invloede van ander wêreldbeskouings. Om kinders se lewens- en geloofsvrae te beantwoord en om die vorming van 'n bybels-Christelike wêreldbeskouing aan te help, is gefokusde toerusting noodsaaklik. Wat die apologetiese aspek aanbetref, is Baucham Jr. (2015:87) van mening dat so 'n bybels-Christelike wêreldbeskouing slegs akkuraat gevorm kan word wanneer daar 'n suiwer bybelse Christelike leer gekweek word: 'When most Christians think apologetics training, they think philosophy, logic, and debate. However, the key tools for training the expository apologist are creeds, confessions, and catechisms.'

Carter (2012:25) toon dan ook uit resente navorsing in kinderontwikkeling (vgl. Morgenthaler 1999; Stonehouse 2007; Westerhoff 2000; Yust 2004) aan dat 'n bybelse wêreldbeskouing eksplisiet aan voorskoolse kinders geleer kan word. Trouens, in sy eie navorsing van 46 uur observasie van vierjariges, bevind Carter (2012:67) dat hierdie kinders in die tydgreep 44 verwysings na 'n bybelse wêreldbeskouing gemaak het en dit selfs kon verdedig. Dit is noodsaaklik dat ouers aan hierdie geloofsvorming en toerusting deelneem sodat kinders die nodige onderbou sal hê om hulleself ten opsigte van hulle Christelike geloof en wêreldbeskouing te kan verantwoord (vgl. Van Niekerk 2018; Venter 2019:27-40).

Wat wêreldbeskouing betref, het Sire (2009:22-24) in sy navorsing bevind dat daar veral sewe vrae is waarop almal antwoorde wil gee. Vir die Christenkind is die Bybelverhale waarmee kinders tans groot word genoegsaam om ten minste vyf van hierdie vrae direk te beantwoord. Hierdie vyf aspekte handel (1) oor God; (2) die mens; (3) die toekoms (eskatologie); (4) die hede (etiek); en (5) die verlede (verbondsgeskiedenis). By die oorblywende twee dien die Bybel steeds as primêre bron in die leefwêreld van voorskoolse kinders, maar daarby word gewoonlik ook ander bronne betrek. Hierdie twee elemente is (6) natuur (wetenskappe en skepping); en (7) ander godsdienste (wêreldbeskouings).

Carter (2012) se beskrywing van 'n bybelse wêreldbeskouing bied insig met betrekking tot navorsing oor 'n bybelsChristelike wêreldbeskouing by voorskoolse kinders:

$[A]$ view of the world that is about the general nature of reality informed by the divinely inspired Holy Bible and which affects or enables the practitioner to think theologically about every decision of life ... In a broad sense, a Biblical worldview is similar to a Christian theistic worldview in that actions and life decisions are filtered through the lens of the Holy Bible's instructions ... A Biblical worldview then is held by those who have internalized Bible knowledge and attempted to live it out by practicing a love for God while in relationship with God and others. (pp. 23-25)

Hierdie werklikheid bestaan ook by voorskoolse kinders wat progressief aan die vorming van hulle wêreldbeskouing bou. Hieroor skryf Malan (1979):
Die kind [kleuter] soek antwoorde op die volgende vrae: Wie is ek? Hoekom is ek hier? Waar kom ek vandaan? Wie is jy? Hoe lyk ons wêreld? Hy vind antwoorde op sy vrae deur die omgewing te verken, vrae te stel en self dinge te ontdek. Die kind se persoonlikheid word grootliks in die eerste vier jaar gevorm. Hier word sy gesindheid teenoor ander mense, teenoor God en die wêreld rondom hom vasgelê. (bl. 24)

Terwyl ander wêreldbeskouings Christene se voorskoolse (verbonds-)kinders in die vorming van 'n bybelsChristelike wêreldbeskouing (veral in die multimedia wêreld van vandag) negatief kan beïnvloed, kan die integrering van gefokusde apologetiese toerusting met geloofsopvoedingskurrikula nie net die klein kindertjies help in hulle eie groei en insig nie, maar ook aan hulle geleentheid bied om antwoorde te gee en te reageer op idees wat hiermee verskil.

\section{Apologetiese toerusting in kategetiese onderrig}

\section{Die behoefte aan voldoende kategetiese kurrikula vir voorskoolse kinders}

Mensing (1972) wys op die noodsaaklikheid vir 'n behoorlike Christelike kurrikulum by voorskoolse kinders wanneer hy stel:

If the church wishes to meet its challenge in child training properly, it must offer a modern, efficient, and challenging program of preschool education to guide and direct the children during their most impressionable years. (p. 14)

Volgens hom is die doel van 'n kleuterskool met 'n Christelike oriëntasie en kurrikulum om tuisgeloofsonderrig te ondersteun sodat kinders ' $n$ liefde vir die Bybel sal ontwikkel en om so tot die besef te kom dat God, die Skepper, steeds aktief betrokke is. Ook dat God, in ons Here Jesus Christus, hulle uit genade verlos van die oordeel oor die sonde. Dit is hierdie ware en enigste God wat hulle gemaak het, liefhet en in verhouding met hulle staan deur die Heilige Gees wat altyd by hulle is. Die hoofdoel van so 'n Christelike kleuterskool is dus om kinders se geloof in aksie te bring (Mensing 1972:15).

Hierdie opmerking geld natuurlik nie net vir kleuterskole nie, maar ook vir ouers se verbondsopvoeding en kerklike kategese.

\section{Theunissen (1978) stel dat die voorskoolse jare 'n tyd is:}

vir die aanleer van gesindhede: positiewe houdinge ten opsigte van godsdiens, liefde vir die alomteenwoordige God, 'n begeerte om Hom beter te leer ken, dankbaarheid vir alles wat Hy ons gee en berou oor wat ons verkeerd doen. (bl. 10)

Aansluitend hierby beskou Ratcliff (1988:233-235) die aanleer van drie basiese konsepte oor God, naamlik sy liefde, sy oneindigheid en dat God Gees is as die mees fundamentele sake wat voorskoolse kinders moet ken voordat hulle enige iets anders aanleer. Met hierdie drie konsepte sal kinders in staat gestel word om 'n beter begrip van God te hê. 
Met betrekking tot Bybel- en geloofsonderrig aan kinders, toon Gert Breed (1994:288-292) dat in die Ou en Nuwe Testament daar basies drie wyses van onderrig na vore kom: Eerstens word kinders deur mondelinge oordrag geleer (bv. deur Woordverkondiging, huisgodsdiens, ens.); tweedens deur middel van die voorbeeld van hulle ouers en/of leermeesters; en laastens deur hulle eie sowel as die gemeenskap se geloofsuitlewing. Breed stel verder dat kinders tot en met die Reformasie geen formele kategetiese onderrig ontvang het nie. Kinders is vroeër deur hul ouers, mense met 'n besondere onderrigroeping, Joodse feeste, die volk van God, sowel as deur eredienste onderrig (Breed 1994:255-256). Elkeen van hierdie dimensies het God se verbond as grondslag en plaas afsonderlik 'n spesifieke klem daarop. Daarom kom Breed (1994:265) tot die gevolgtrekking dat geloofsopvoeding verbondsopvoeding is in die sin dat verbondsopvoeding die geloofsopvoeding bepaal en vasstel juis omdat geloofsopvoeding oor God se verhouding met sy volk gaan. In hierdie opsig is daar nog 'n dimensie van geloofsonderrig wat in die loop van kerkgeskiedenis ontstaan het, naamlik kategetiese onderrig. ${ }^{14}$ Soos kategetiese onderrig veral in die tyd van die Reformasie nodig geword het om in die bybelse leer onderrig te word en dit te kon verdedig nadat die Bybel vir lank nie beskikbaar was nie, het voorskoolse kategese die laaste dekades nodig geword omdat klein kindertjies en hulle ouers voortdurend met leer wat in stryd is met die Christelike lewensen wêreldbeskouing gekonfronteer word..$^{15}$

\section{Apologetiese toerusting ' $n$ noodsaak in kategetiese kurrikula by voorskoolse kinders}

Die noodsaaklikheid van apologetiese toerusting by voorskoolse kinders blyk verder uit Doherty (1996:4) se opmerking: 'Most, if not all, children's workers will agree that one of the greatest problems we face today is that the vast majority of boys and girls have very little, or no, understanding of Bible truth.'

Sy uiteensetting van waarom kinders in-diepte onderrig in die Christelike leer moet ontvang, is van belang vir die daarstel van 'n apologetiese kurrikulum; spesifiek wanneer hy stel dat hedendaagse kinders in ' $\mathrm{n}$ geweldige moeilike wêreld leef waar ander sienings en wêreldbeskouings in oormaat gepropageer word. In 'n wêreld van materialisme, humanisme, agnostisisme, ateïsme, hedonisme, eksistensialisme, okkultisme en vele ander, ${ }^{16}$ is die enigste verweer dat kinders met bybelse waarhede toegerus word

14 . Calvyn het kategetiese onderrig aan kinders so sterk beklemtoon dat hy dit in 1541 in die kerkorde laat vasmaak het Tog het hy geen onderskeid tussen die in die kerkorde lat vasmaak het. Tog het hy geen onderskeid tussen die kategismuspreek en kategetiese onderrig aan kinders getref nie. Kinders is dus tydens die gemeentebyeenkomste in die kategismus onderrig. Sodoende het hy dit reggekry dat kategetiese onderrig nie losstaande van ouers se onderrig was nie, maar juis aanvullend sodat ouers ook toegerus kon wees om hulle kinders in die verbondswaarhede te onderrig (Breed 1994:267-269).

15.Van die verkrygbare bronne wat onder andere op die vorming van wêreldbeskouing op laerskoolvlak fokus, is Elizabeth Urbanowicz (2019) se Foundation comparative worldview curriculum (wat spesifiek op wêreldbeskoulike vrae toespits) en Summit_Ministries (2019) se Build on the Rock curriculum (wat reeds op voorskoolse vlak op die integrasie van Bybelverhale en wêreldbeskouings fokus). Wat boeke aanbetref, het daar onlangs drie publikasies die lig gesien wat goeie Wat boeke aanbetref, het daar onlangs drie publikasies die lig gesien wat goeie Talking to your kids about God (Crain 2017) en Hillary Morgan Ferrer (2019) se Mama Bear apologetics.

16.Verdere gegewens oor van hierdie beskouings kan onder andere verkry word van Geisler (2015:16-20 [agnostisisme], 55-60 [ateïsme], 193-196 [eksistensialisme] 353-357 [humanisme], 453-457 [materialisme]). sodat hulle in staat sal wees om hulleself ten opsigte van 'n bybelse wêreldbeskouing te kan verantwoord (Doherty 1996:15-16).

Net soos met volwassenes, word Christenkinders op voorskoolse vlak reeds deur valse wêreldbeskouings gekonfronteer en selfs beïnvloed. Hulle moet daarom reeds van kleins af vanuit die Woord van God toegerus en ingeskerp word om 'n korrekte wêreldbeskouing te vorm. Hierdie vertrekpunt moet ooreenstem met die werklikheid van God, die mens, sy wêreld asook sy herkoms, eindbestemming, rede vir bestaan en die norme wat daarvoor geld. ${ }^{17}$ Deur ' $n$ toespitsing op apologetiese toerusting in bybelse onderbou en die Christelike leer word voorskoolse kinders toegerus om te kan onderskei en hulleself apologeties teen ander wêreldbeskouings te verantwoord.

Selfs met die oplewing in die studieveld van Apologetiek vandag, ontbreek apologetiese toerusting in terme van' $n$ bybelsChristelike wêreldbeskouing (inhoudelik en metodologies) grootliks by voorskoolse kinders se geloofsopvoeding. Nadenke oor hoe dit by geloofsopvoedingskurrikula geïntegreer kan word om aan die genoemde leemtes van voorskoolse kinders se geloofsverantwoording te beantwoord, word al hoe belangriker.

\section{Hoe apologetiese toerusting by voorskoolse kategetiese onderrig betrek kan word}

Apologetiek as vakwetenskap is onder andere daarop toegespits om 'n rasionele regverdiging vir die waarhede van die Christelike geloof te bied (Craig 2008:15). Dit handel kortliks oor die verdediging van geloof (vgl. Frame \& Torres 2015:xxxv) en dit kan as antwoord aan die ongelowige op bybelse waarheid beskou word (Oliphint 2013:29). Stoker (2017) stel dit soos volg:

The focus of apologetics, accordingly, is to give a reasoned response to the attacks of opponents, as well as to answer the probing questions of those who wonder about the gospel and aspects thereof. (p. 43)

Baucham Jr. (2015:20) beklemtoon dat Christene moet weet wat en waarom hulle glo: 'In its simplest form, apologetics is knowing what we believe and why we believe it, and being able to communicate that to others effectively.' In hierdie verband is dit nodig dat selfs voorskoolse kinders gereed sal wees om hulleself op hulle vlak oor hulle Christelike geloof te kan verantwoord.

Wat apologetiese toerusting betref, stel Venter (2019) vier riglyne vir ouers en opvoeders voor wat in voorskoolse kinders se ontwikkeling tot apologetiese verantwoording sal bydra. Hierdie apologetiese riglyne sluit onder andere in dat ouers hulle geloof sal uitleef en dat hulle hul kinders die Christelike wêreldbeeld sal leer en ander godsdienste in perspektief sal plaas. Dit sluit verder in dat kinders spesifiek toegerus sal word om hulle geloof teenoor ander godsdienste te kan verdedig, en dat ouers die stimulering van geloofsgesprekke as 'n lewenstaak sal opneem (Venter 2019:40-48).

17.Laasgenoemde vier sake word deur die bekende apologeet, Ravi Zacharias (2018) as die kern van die apologetiese oorweging van ' $n$ wêreldbeskouing gesien. 
Om ouers in hulle bybelse opdrag van tuisgeloofsonderrig te ondersteun, moet kerke genoegsame apologetiese toerusting wat op voorskoolse kinders gerig is in katkisasiehandleidings bied. Kinders moet spesifiek op geestelike terrein in hulle vormingsjare reeds met ' $n$ bybelsChristelike wêreldbeskouing wat juis ook apologeties gefokus is, toegerus word.

Met God se verbond as grondslag en 'n gesonde bybelsChristelike geloofsonderrig en leer, behoort apologetiese toerusting in kategetiese onderrig veral op wêreldbeskoulike vrae wat ontologiese vrae insluit oor (1) God; (2) die mens; (3) die toekoms; (4) die hede; (5) die verlede; (6) die natuur; en (7) ander godsdienste te fokus. Sodoende word kinders toegerus om te verstaan dat die werklikheid rondom hulle ooreenstem met dit wat die Bybel oor God, die mens en sy wêreld leer, en kan voorskoolse kinders die waarheid van die Christelike geloof op 'n liefdevolle en respekvolle wyse aan ander mense stel (vgl. Ef 4:15).

\section{Enkele voorbeelde van apologetiese toerusting by voorskoolse kategese}

Wanneer Bybelkennis vir voorskoolse kinders aangeleer word, is dit belangrik om telkens die Godsbeskouing wat spesifiek in die Skrifgedeelte openbaar word as vertrekpunt uit te lig sodat hierdie kinders God waarlik kan ken en die res van die werklikheid vanuit hierdie vertrekpunt kan benader (Richards 1970:289). Voorskoolse kinders behoort daarom ten minste die volgende van die drie-enige God te weet (Richards 1970:303-304; vgl. Doherty 1996:35-37):

- Dat God persoonlik is, alles weet en sien en dat Hy alles kan doen;

- dat God vir ons omgee en ons hoor wanneer ons met Hom praat;

- dat God die wêreld goed gemaak het en dit vir ons gee om te geniet: oë om te sien, sterk bene, ouers, 'n huis, ensovoorts;

- dat Jesus die Seun van God is wat ons liefhet en ook ons liefde vir Hom wil hê;

- dat Jesus werklik lewe, dáár is vir ons, en ons leer hoe om God te dien;

- dat ongehoorsaamheid aan God sonde is; maar

- dat Jesus vir ons sonde gesterf het en God ons so van ons sonde vergewe.

Wanneer 'n bybels-Christelike leer vir kinders aangeleer word, gee Doherty (1996:21-23) sewe praktiese beginsels wat gevolg moet word: Dit moet (1) eenvoudig; (2) aantreklik; (3) logies en sistematies; (4) spesifiek; (5) prakties; (6) behulpsaam; en (7) biddend wees. Hierby voeg Richards (1970:303) dat 'n kind se speelvermoëns sy leersoektog is, en dat onderrig aan voorskoolse kinders dus hulle sintuie, ervarings en aktiewe spel moet insluit, terwyl hulle terugvoer of respons tegelykertyd aangemoedig moet word (vgl. Richards 1970:290; ook Espinoza, Estep \& Morgenthaler 2018: loc. 751). Die teoloog, James Fowler, wat bekend is vir sy teorie van geloofsontwikkeling, voeg hierby die noodsaaklikheid van beelde en stories wat onmisbaar vir voorskoolse kinders se verbeelding is en dus by geloofsopvoeding ingesluit moet word (Fowler 1981:129-133). ${ }^{18}$ Voorbeelde van hoe iemand verskille deur middel van storievertelling op 'n apologeties wyse hanteer het (bv. C.S. Lewis se Narnia), kan hiertoe 'n belangrike bydrae vorm.

Wanneer oor apologetiese toerusting besin word, en in hierdie geval waar dit op voorskoolse kategese toegepas word, beklemtoon Van Til die belangrikheid dat hierdie toerusting vanuitdieSkrifGod-sowel as Christusgesentreerd moet wees om sodoende enige positiewe bydrae te kan maak: 'Only a fully biblical and therefore fully Reformed theology and apologetic can meet the need of the hour' (Edgar 1980:241).

Uit die talle moontlikhede van hoe God-, mens- en wêreldbeskoulike elemente vir klein kindertjies verduidelik kan word, word hier slegs een (en dit kursories) genoem om as voorbeeld te dien, ${ }^{19}$ naamlik die bekende verhaal van Saggéüs wat graag die Here Jesus wou sien (Luk 19:110). Die verhaal beeld God se liefde vir verlore mense uit, asook dat die Here Jesus juis hiervoor gekom het (vanwaar en waartoe - v. 10). Verder word die sondige selfsug van die mens uitgebeeld, maar ook die impak van verlossing (v. 8). Dit vertel van ons eienaarskap en eiendom in die wêreld (vv. 4, 5, 8), asook norme wat daarvoor geld (v. 8). Dit spreek ook van ons lewensdoel sowel as -opoffering (vv. 7, 9, 10) en hoe geloof tot dade oorgaan (vv. 8, 9). Daarby bied dit 'n antwoord op verskeie dwalings en valse gelowe.

\section{Ten slotte}

As deel van ' $n$ huldigingsbundel vir prof. Gert Breed is dit kosbaar om soveel aspekte wat in die artikel uiteengesit is, in sy woorde saam te vat (Breed 2019):

Ons moet seker maak dat ons die kinders in die volle waarheid lei en hulle begelei om dit aan te neem en hulle eie te maak. 'n Ware kind ken sy Vader reg, daarom het hy Hom lief en vertrou Hom. Uit die kennis en liefdesvertroue vloei die gehoorsaamheid voort. Maak ons seker dat die kinders die waarheid begryp, dit aanneem en dit uitleef? Of duld ons maar dat hulle volgens die leuens van Satan leef solank hulle met die mond reg bely? ... Ware kinders kan ons alleen kry as ons seker maak dat ons kinders voortdurend groei in kennis, liefde en gehoorsaamheid ... Ons moet hulle lei om met hulle harte na God te kom. So word hulle kinders in die huis van die Here. Kinders wat sal bly en die Here voluit sal dien (vgl. 1 Joh 2:3-6). (bl. 9)

18.In'n boek wat onlangs deur Espinoza et al (2018: loc. 691) gepubliseer is, word die volgende in verband met storie-vertelling beklemtoon: 'Bible storytelling is a process that actively connects the teller with the listener, through language imagination, and shared understanding (Morgenthaler et al. 2014). When used imagination, and shared understanding (Morgenthaler et al. 2014). When used effectively, it is uniquely placed to be a powerful medium for communicating meaning, faith, spiritual awareness, biblical knowledge, and values to young hildren aged three to five years. It invites the listeners to use their head, heart, and
hand in the development of their spiritual awareness and faith formation.'

19.Meer praktiese voorstelle sou verkry kon word van Natasha Crain (2017) se boek, Talking with your kids about God. 


\section{Erkenning}

Die outeurs is deel van die Navorsingeenheid vir Reformatoriese Teologie (ERT) van Fakulteit Teologie van die Noordwes-Universiteit,

\section{Mededingende belange}

Die skrywers het verklaar dat daar geen kompeterende belang is nie.

\section{Outersbydrae}

Die artikel vorm deel van Jonker Venter se PhD-studies onder leiding van Henk Stoker.

\section{Etiese oorwegings}

Hierdie artikel voldoen aan alle etiese standaarde vir navorsing sonder direkte kontak met mense of diere. (Etieknommer: NWU-00781-21-A7).

\section{Befondsing}

Hierdie navorsing het geen spesifieke toekennings ontvang van 'n befondsingsagentskap in die openbare, kommersiële of nie-winsgewende sektore nie.

\section{Data beskikbaarheid}

Die studie is 'n literatuurstudie met al die bronne beskikbaar in die openbare domein.

\section{Vrywaring}

Menings uitgespreek in die artikel is die van die outeurs en nie noodwendig die siening van die NWU nie.

\section{Literatuurverwysings}

Barna Group, 2018, Gen Z: The culture, beliefs and motivations shaping the nex generation, Barna Group and Impact 360 Institute, Ventura, CA.

Baucham, Jr., V., 2015, Expository apologetics: Answering objections with the power of the word, Crossway, Wheaton, IL.

Breed, G., 1994, 'Kategese en geloofsopvoeding', PhD proefskrif, Potchefstroomse Universiteit vir Christelike Hoër Onderwys, Potchefstroom.

Breed, G., 2019, 'Die heerlike roeping van die kategeet', Die Kerkblad, November, pp. $8-10$

Bunge, M.J. (ed.), 2001, The child in Christian thought, Eerdmans, Grand Rapids, MI.

Bunge, M.J. (ed.), 2008, The child in the Bible, Eerdmans, Grand Rapids, MI.

Carter, D.L, 2012, 'Biblical worldview expression in four-year-olds', PhD thesis, Union Institute \& University, Cincinnati.

Craig, W.L., 2008, Reasonable faith: Christian truth and apologetics, 3rd edn., Crossway Books, Wheaton, IL.

Crain, N., 2016, Keeping your kids on God's side, Harvest House Publishers, Eugene, OR.

Crain, N., 2017, Talking to your kids about God, Baker, Grand Rapids, MI.

De Klerk, B.J. \& Van Helden, P., 2011, 'Oorsake van kerkkrimping binne die tradisioneel Afrikaanssprekende Gereformeerde Kerke in Suid-Afrika', Verbum et Ecclesia 32(1), 1-10. https://doi.org/10.4102/ve.v32i1.477

Doherty, S., 1996, How to teach Bible doctrines to children, Child Evangelism Fellowship, Lisburn.

Edgar, W., (ed.), 2003, Christian apologetics, 2nd edn., P\&R Phillipsburg, NJ.
Espinoza, B.D., Estep, J.R. \& Morgenthaler, S.K. (eds.), 2018, Story, formation, and culture: From theory to practice in ministry with children, Pickwick Publications, Eugene, OR. [Kindle edn.]

Ferrer, H.M., 2019, Mama Bear apologetics, Harvast House, Eugene, OR.

Fowler, J.W., 1981, Stages of faith: The psycology of human development and the quest for meaning, HarperCollins, New York, NY.

Frame, J.M. \& Torres, J.E., 2015, Apologetics: A justification of christian belief, 2nd edn., P\&R Publishing, Phillipsburg, NJ.

Geisler, N.L., 2015, The big book of christian Apologetics, Baker, Grand Rapids, MI.

Kaiser, W.C. \& Silva, M., 2007, Introduction to biblical hermeneutics: The search for meaning, Zondervan, Grand Rapids, Ml.

Keeley, R.J., 2008, Helping our children grow in faith: How the church can nurture the spiritual development of kids, Baker, Grand Rapids, MI.

Louw, D.A. \& Louw, A.E., 2014, Child and adolescent development, 2nd edn., Psychology Publications, Bloemfontein.

Malan, G., 1979, God en die kleuter, NG Kerkboekhandel, Kaapstad.

May, S., Posterski, B., Stonehouse, C. \& Cannell, L., 2005, Children matter: Celebrating their place in the church, family, and community, Eerdmans, Grand Rapids, MI.

Mensing, M, 1972, Today's Christian kindergarten, Concordia, Saint Louis, MO.

Morgenthaler, S.K., 1999, Exploring children's spiritual formation: Foundational issues, Pillars, River Forest.

Oliphint, K.S., 2013, Covenantal Apologetics: Principles and practice in defense of our faith, Crossway, Wheaton, IL.

Ratcliff, D., (ed.), 1988, Handbook of preschool religious education, Religious Education, Birmingham, AL.

Richards, A. \& Privett, P., (eds.), 2009, Through the eyes of a child: New insights in theology from a child's perspective, Church house, London.

Richards, L., 1970, Creative Bible teaching, Moody Publishers, Chicago, IL.

Richards, L., 1975, A theology of Christian education, Ministry Resource Library, Grand Rapids, Ml.

Shaffer, D.R. \& Kipp, K., 2010, Developmental psychology: Childhood and adolescence, 8th edn., int. edn., Wadsworth, Cengage Learning, Mason, $\mathrm{OH}$

Sire, J.W., 2009, The universe next door: A basic worldview catalog, 5th edn., InterVarsity Press, Downers Grove, IL.

Sire, J.W., 2015, Naming the elephant: Worldview as a concept, 2nd edn., IVP Academic, Downers Grove, IL.

Stoker, H.G., 1961, Beginsels en metodes in die wetenskap, Pro Rege-Pers, Potchefstroom.

Stoker, H.G., 2017, 'Convinced by Scripture and plain reason: Reasonable reformational apologetics', in S.P. van der Walt \& N. Vorster (eds.), Reformed theology today: Practicaltheological, missiological and ethical, perspectives, pp. 41-59, AOSIS, Cape Town

Stonehouse, C., 2007, Joining children on the spiritual journey: Nurturing a life of faith, Baker, Grand Rapids, MI.

Strommen, M.P. \& Hardel, D., 2008, Passing on the faith: A radical model for youth and family ministry, rev. edn., Saint Mary's, Winona, MN.

Summit Ministries, 2019, Building on the rock Bible curriculum, viewed 19 September 2019, from https://www.summit.org/curriculum/building-on-the-rock.

Theunissen, A., 1978, Vernaamstes in die koninkryk: Godsdiensleiding vir die voorskoolse kind, Tafelberg, Kaapstad.

Urbanowicz, E., 2019, Foundation comparative worldview curriculum, viewed 19 September 2019, from https://foundationworldview.com.

Valk, J., 2012, 'Christianity through a worldview lens', Journal of Adult Theological Education 9(2), 158-174.

Van der Merwe, C.N., 2004, 'Kategese as middel tot heilsekerheid en heilstoe-eiening in konteks van die verbond en die koninkryk', PhD proefskrif, Noordwes-Universiteit, Potchefstroom.

Van der Walt, B.J., 2010, At home in God's world: A transforming paradigm for being human and for social involvement, The Institute for Contemporary Christianity in Africa, Potchefstroom.

Van Niekerk, M., 2018, 'The role of parents in the development of faith during a child's formative years', MTh dissertation, North-West University, Potchefstroom.

Venter, G.J., 2019, 'Geloofsvorming en die vermoë om geloof te verdedig by kinders onder sewe jaar as korrektief op nominale Christendom', MTh-verhandeling, Noordwes-Universiteit, Potchefstroom.

Weiten, W., 2014, Psychology: Themes and variations, South African edn., Cengage Learning, Andover, Hampshire.

Westerhoff, J.H., 2000, Will our children have faith?, rev. edn., Morehouse, Toronto.

Yust, K.M., 2004, Real kids, real faith: Practices for nurturing children's spiritual lives, John Wiley \& Sons, San Francisco, CA.

Yust, K.M., Johnson, A.N., Sasso, S.E. \& Roehlkepartain, E.C. (eds.), 2006, Nurturing child and adolescent spirituality: Perspectives from the world's religious traditions, Rowman \& Littlefield, Lanham, MD.

Zacharais, R., 2018, Defending the faith: 2018 West Coast conference, viewed 12 January 2021, from https://www.ligonier.org/learn/conferences/defendingthe-faith-2018-west-coast-conference/origin-meaning-morality-destiny. 